\title{
THYROTOXIC PERIODIC PARALYSIS: A CASE REPORT
}

\author{
Jadranka Morović-Vergles ${ }^{1}$, Branko Ostrički ${ }^{1}$, Krešimir Galešić ${ }^{1}$, \\ Mirko Skoro ${ }^{1}$ and Dijana Zelenika ${ }^{2}$ \\ ${ }^{1}$ Department of Medicine, Dubrava University Hospital, Zagreb, Croatia, and ${ }^{2}$ Department of Medicine, \\ Mostar Clinical Hospital, Mostar, Bosnia and Herzegovina
}

\begin{abstract}
SUMMARY - A case of thyrotoxic periodic paralysis in a 24-year-old male with hyperthyroidism is presented. Clinical manifestations included progressive symmetrical weakness that led to flaccid paralysis due to hypokalemia with concurrent thyrotoxicosis. Intravenous administration of potassium chloride resulted in complete regression of the symptoms of muscle weakness and paralysis. Hypokalemic periodic paralysis is an uncommon complication of thyrotoxicosis, which primarily occurs in Orientals, with a high male predominance, and has rarely been described in Caucasians.
\end{abstract}

Key words: Thyrotoxicosis, complications; Hypokalemia, complications; Paralysis, etiology; Case report

\section{Introduction}

Periodic paralysis is a rare complication of hyperthyroidism ${ }^{1}$. It has been described in diverse racial and ethnic groups ${ }^{2-4}$, predominantly in Oriental and LatinAmerican young males ${ }^{5-7}$. Thyrotoxic periodic paralysis (TPP) is a disorder characterized by concurrent thyrotoxicosis, hypokalemia and progressive symmetrical weakness leading to paralysis of extremities and other muscle groups. In TPP, hypokalemia is usually associated with hypophosphatemia and mild hypomagnesemia ${ }^{4}$. The pathophysiology of TPP remains largely unexplained and controversial.

In this report, clinical and biochemical findings in a young man with hyperthyroidism who experienced three attacks of periodic paralysis are described. All three attacks occurred during or shortly after sleep. The first two attacks of muscle weakness required no medical intervention and resolved spontaneously. On the third attack, however, the

Correspondence to: Professor Jadranka Morovic-Vergles, M.D., Ph.D., Department of Medicine, Dubrava University Hospital, Avenija Gojka Šuška 6, HR-10000 Zagreb, Croatia

E-mail: jmorovic@kbd.hr

Received January 18, 2002, accepted April 26, 2002 patient was admitted to the hospital for complete muscle paralysis, which regressed upon intravenous administration of potassium chloride. The attacks of TPP ceased completely with resolution of the hyperthyroidism.

\section{Case Report}

A 24-year-old male was admitted to the Emergency Unit for myalgia and abrupt onset of tetraparesis after several hours of sleep. History data revealed similar attacks to have occurred on two occasions in the past four months, during the night or at dawn, which spontaneously regressed within a few hours. The patient had not been hospitalized before. Six months before, the patient had experienced tremor of his hands, hyperhidrosis, palpitations, nervousness, and hyperorexia with weight loss. Three months after the onset of these symptoms, the diagnosis of hyperthyroidism was made and therapy with metamizole was initiated. After seven days, this therapy had to be discontinued due to pronounced side effects (polyarthralgia, myalgia, generalized urticaria), and propylthiouracil was introduced, which was well tolerated by the patient. The patient had normal appetite, normal urination, and frequent evacuation (up to 4 loose stools daily). He smoked about 20 cigarettes a day, and used no alcohol drinks. 
On examination at the Emergency Unit, the patient was immobile due to tetraparesis, conscious, moist skin, afebrile, eupneic. There were no cranial nerve symptoms. The thyroid was enlarged and insensitive on inspection and palpation. Rhythmical heart action, c/p 96/min, blood pressure 130/80 mm Hg. Normal respiratory sound over the lungs. The abdomen soft, insensitive on palpation, no organomegaly. Mild edema of the metacarpophalangeal articulation I. Flaccid tetraparesis.

Laboratory findings on admission: one-hour erythrocyte sedimentation rate (ESR) 3; complete blood count (CBC), blood glucose (BG), creatinine, transaminases, bilirubin, creatine phosphokinase $(\mathrm{CPK})$, and lactic dehydrogenase (LDH) were normal; potassium (K) 1.5 (normal range $4.1-5.5$ ) $\mathrm{mmol} / \mathrm{L}$.

Laboratory findings during hospitalization: phosphorus $(\mathrm{P}) 2.11(0.65-1.62) \mathrm{mmol} / \mathrm{L}$; magnesium $(\mathrm{Mg}) 0.62$ (0.45 - 1.15) mmol/L; calcium (Ca) 2.52 (2.25 - 2.75) mmol/L; chloride (Cl) 101 (95 - 105) mmol/L. Electrolytes in 24-hour urine: potassium (K) $140(60-80) \mathrm{mmol} /$ DU.

Arterial blood gases and acid - base balance were within the normal range. Urine: $\mathrm{pH}$ 5.0; specific weight 1.025; sediment normal; 24-hour urine protein negative. Thyroid hormones: thyroxine $\left(\mathrm{T}_{4}\right) 185(71-141) \mathrm{nmol} / \mathrm{L}$; triiodothyronine $\left(\mathrm{T}_{3}\right) 8.1(1.5-2.6) \mathrm{nmol} / \mathrm{L}$; thyroid-stimulating hormone $(\mathrm{TSH})<0.02(0.27-4.68) \mathrm{mU} / \mathrm{L}$, indicating hyperthyroidism. Cortisol, aldosterone and plasma renin activity were within the reference values. Waaler-Rose, latex and dsDNA tests were negative. Thyroid ultrasonography (US) indicated diffuse goiter; computed tomography (CT) of adrenal glands showed no pathologic alterations; upper abdomen US was normal; electromyoneurography (EMNG) of upper and lower extremities revealed no myopathic cause; gastroscopy and rectoscopy yielded normal findings, and so did stool parasitology and bacteriology.

Upon admission, the patient received $40 \mathrm{mmol}$ potassium chloride i.v., which resulted in complete regression of tetraparesis. The treatment of hyperthyroidism was continued by propylthiouracil. On control outpatient examinations after restitution of euthyroidism, the patient was subjectively well, free from TPP attacks, and with normal serum potassium values.

\section{Discussion}

Most common clinical manifestations of hypokalemia (serum potassium $<3.5 \mathrm{mmol} / \mathrm{L}$ ) include neuromuscular (muscle weakness, rhabdomyolysis, ileus), cardiovascular (ventricular arrhythmias, hypotension, arrest), renal (polyuria, nocturia), and metabolic (hyperglycemia) disturbances. Hypokalemia can be induced by various causes: 1 ) reduced potassium intake (anorexia nervosa, deficient nutrition in alcoholics); 2) gastrointestinal losses (vomiting, diarrhea, laxative abuse, fistulas, villous adenoma, ureterosigmoidostomy); 3) intracellular potassium shift (metabolic alkalosis, insulin and adrenergic agonist overdosage, hypokalemic periodic paralysis, theophylline, barium and toluene intoxication); 4) renal losses (diuretics, aminoglycosides, penicillin antibiotics, primary and secondary hyperaldosteronism, Bartter's syndrome, excessive intake of exogenous mineralocorticoids, Cushing's syndrome, ectopic ACTH secretion, renal tubular acidosis, leukemias, magnesium depletion); and 5) some hereditary disorders (familial hypokalemic periodic paralysis, congenital androgenital syndrome, Little's disease, familial interstitial nephritis).

We have presented a 24-year-old man admitted to the Department of Medicine Emergency Unit and transferred to the ward for tetraplegia associated with pronounced hypokalemia (potassium level, $1.5 \mathrm{mmol} / \mathrm{L}$ ). Hyperthyroidism had been diagnosed on an outpatient basis three months before the present admission, and the patient sustained episodes of muscle weakness progressing to complete paralysis of the extremities on three occasions. The attacks occurred immediately after sleep and regressed spontaneously in several hours on two occasions. The third attack, which occurred following discontinuation of metamizole therapy, required medical attention and the patient was admitted to our emergency room. On his presentation to the emergency room, the diagnosis of thyrotoxic periodic paralysis was initially failed, however, the accurate diagnosis of thyrotoxic hypokalemic periodic paralysis (THPP) was subsequently made. THPP is a rare complication that sporadically occurs, mostly in young males of Asian and Latin-American origin ${ }^{2,4-7}$, and considerably less commonly in Caucasians and blacks ${ }^{3,8-10}$. According to the literature data available, the incidence of THPP in hyeperthyroidism patients ranges from $0.1 \%$ - $0.2 \%$ in American Caucasians ${ }^{10}$ to $4.3 \%$ in Japanese ${ }^{5}$. The male to female ratio is $20: 1^{5}$.

Clinically, THPP cannot be differentiated from familial periodic paralysis, although the former predominantly affects males, rarely is associated with positive family history, and develops later in life. There was no case of periodic paralysis among close relatives of our patient. The initial clinical manifestations of THPP include myalgia 
and progressive muscle weakness with exacerbation to paralysis of the extremities. Laboratory findings show hypokalemia (100\%), hypophosphatemia (80\%), and mild hypomagnesemia ${ }^{4}$. Rebound hyperkalemia occurs in some $40 \%$ of patients ${ }^{4}$. In our patient, marked hypokalemia was corrected by $40 \mathrm{mmol}$ potassium chloride i.v. (the levels of magnesium and phosphorus were not determined in Emergency Room). On day 2 of admission, however, the levels of potassium and magnesium were within the normal limits. The finding of mild hyperphosphatemia, recorded on day 2 of admission, is consistent with literature data on mild to moderate hypophosphatemia being recorded when phosphorus was determined within 1.5 hour from admission to hospital, or while the level of potassium was still low; upon paralysis resolution, the level of phosphorus returned to normal or was slightly elevated ${ }^{4}$. THPP usually occurs in patients with Graves' disease, however, any cause of hyperthyroidism including excessive use of a substitute may lead to this disorder. The clinical and laboratory parameters of hyperthyroidism may be latent or very discrete. In our patient, hyperthyroidism was diagnosed three months before his admission to the Department and showed overt clinical manifestations. The attacks of periodic paralysis, such as those that occurred in our patient, may be precipitated by the rest (sleep). TPP attacks after several hours of sleep are usually preceded by extreme physical activity or excessive carbohydrate intake ${ }^{10}$. Attacks of periodic paralysis may (although not always) be experimentally induced by a provocation test with glucose $(3 \mathrm{~g} / \mathrm{kg})$ and insulin $(0.1 \mathrm{IU} / \mathrm{kg} \text { i.v. })^{11}$.

Pathophysiologically, various attempts have been made to explain THPP, e.g., by the intracellular shift of potassium due to thyroxine-stimulated enhancement of $\mathrm{K}-\mathrm{Na}$ ATP-ase activity on cellular membrane, or by dynamic disturbances, or by some morphological features of the neuromuscular unit itself ${ }^{2,12}$.

Light microscopy of the muscle biopsy specimens revealed changes in terms of sarcolemmic nuclear proliferation, muscle fiber atrophy, fatty infiltration and vacuolation, while no changes could be detected in one fourth of patients. Electron microscopy generally showed vacuolation (90\%), mitochondrial abnormalities (100\%), accumulation of glycogen granules (100\%), myofibril interruption (50\%), and T-system changes (40\%). These alterations did not correlate with the severity of muscle weakness ${ }^{13}$. In our patient, EMNG of both upper and lower extremities showed no deviations from normal, thus muscle biopsy was not considered necessary. Quadriplegia was promptly reversed by correction of hypokalemia $(40 \mathrm{mmol}$ potas- sium chloride administered as 2-hour i.v. infusion). During the first few days of his hospital stay, renal loss of potassium (hyperkaluria) was recorded, along with clinically and laboratory overt hyperthyroidism. Serum and urine values of other electrolytes, as well as blood pressure, diuresis, arterial blood $\mathrm{pH}$, urine $\mathrm{pH}$, specific weight and sediment, cortisol, aldosterone and plasma renin activity were within the normal limits. The finding of transitory hyperkaluria could not be explained (the increased intracellular concentration of potassium in the main cells of the renal collecting ducts may stimulate its secretion by electrochemical gradient through specific potassium channels in the luminal membrane), however, the available literature provides no data on transient hyperkaluria following THPP attack. Our patient did not develop rebound hyperkalemia after parenteral potassium substitution (perhaps just these patients experiencing transient hyperkaluria after THPP attack and substitution therapy with potassium are not prone to the development of rebound hyperkalemia!?). The episodes of paralysis are reduced by potassium substitution, and attacks can be prevented by the administration of beta-blockers, potassium substitution and spironolactone until restitution of euthyroidism ${ }^{8}$. Definitive treatment of thyrotoxic periodic paralysis should be directed at the establishment of euthyroid state, and it is usually sufficient to prevent the occurrence of spontaneous attacks. Indeed, in our patient, serum levels of potassium normalized with the introduction of propylthiouracil and restitution of euthyroidism, even without potassium substitution and with no record of hyperkaluria.

\section{Conclusion}

On differential diagnosis, thyrotoxic hypokalemic periodic paralysis should be considered in any acute episode of motor paralysis in young patients, especially males. Although the pathogenesis of this dramatic disorder has not yet been fully elucidated, and the reason for sexual and racial predisposition remains unknown, there is strong evidence that successful therapy for hyperthyroidism leads to regression of all clinical and laboratory parameters of the disorder, as also observed in our patient. This is a typical case of thyrotoxic periodic paralysis in an epidemiological group which, to our knowledge, has not yet been described. 


\section{References}

1. MILLIKAN CH, HAINES SF. The thyroid gland in relation to neuromuscular disease. Arch Intern Med 1953;92:5-39.

2. FERREIRO J, ARGUELLES DJ, RAMS H Jr. Thyrotoxic periodic paralysis. Am J Med 1986;80:146-50.

3. KELLY TM, FISHMAN LM. Thyrotoxic periodic paralysis in a black male. J Endocrinol Invest 1984;7:517-9.

4. MANOUKIAN MA, FOOTE JA, CRAPO LM. Clinical and metabolic features of thyrotoxic periodic paralysis in 24 episodes. Arch Intern Med 1999;159:601-6.

5. SHIZUME K, SHISHIBA Y, KUMA K, NOGUCHI S, TAJIRI J, ITO K, NOH JY. Comparison of the incidence of association of periodic paralysis and hyperthyroidism in Japan in 1957 and 1991. Endocrinol Jpn 1992;39:315-8.

6. SAEIAN K, HECKERLING PS. Thyrotoxic periodic paralysis in a Hispanic man. Arch Intern Med 1998;148:708.

7. McFADZEAN AJS, YEUNG R. Periodic paralysis complicating thyrotoxicosis in Chinese. Br Med J Clin Res 1967;1:451-5.
8. OBER KP. Thyrotoxic periodic paralysis in the United States. Report of 7 cases and review of the literature. Medicine (Baltimore) 1992;71:109-20.

9. CELANI MF, BONATI ME, CAVALLI M. Hypokalemic thyrotoxic paralysis in Caucasian male with Graves disease. J Endocrinol Invest 1995;18:228-31.

10. KELLY DE, GHARIB H, KENNEDY FP, DUDA RJ, McMANIS PG. Thyrotoxic periodic paralysis. Report of 10 cases and review of electromyographic findings. Arch Intern Med 1998;149: 2597-600.

11. SCHULZE-BONHAGE A, FIEDLER M, FERBERT A. Periodic paralysis as the first manifestation of hyperthyroidism. Dtsch Med Wochenschr 1996;121:1498-500.

12. ACKERMAN MJ, CLAPHAM DE. Ion channels: basic science and clinical disease. N Engl J Med 1997;336:1575-86.

13. CHEAH JS, TOCK EP, KAN SP. The light and electron microscopic changes in the skeletal muscles during paralysis in thyrotoxic periodic paralysis. Am J Med Sci 1975;296:365-74.

Sažetak

\section{TIREOTOKSIČNA PERIODIČNA PARALIZA: PRIKAZ SLUČAJA}

\section{J. Morović-Vergles, B. Ostrički, K. Galešic, M. Škoro i D. Zelenika}

U radu je prikazan 24-godišnji muškarac s napadajem periodične paralize u hipertireozi. Prikazan je bolesnik s progresivnom simetričnom slabošću koja je dovela do mlohave paralize uslijed hipokalijemije tijekom tireotoksikoze. Nakon parenteralnog dodatka kalija (intravenskom primjenom kalijevog klorida) došlo je do potpunog povlačenja simptoma mišićne slabosti i paralize. Hipokalijemična periodična paraliza rijetka je komplikacija tireotoksikoze opisana u stanovnika Dalekog Istoka, i to prvenstveno u mlađih muškaraca, a iznimno se rijetko javlja u bijelaca.

Ključne riječi: Tireotoksikoza, komplikacije; Hipokalijemija, komplikacije; Paraliza, etiologija; Prikaz slučaja 